\title{
Training Models in Professional Psychology Education (A Literature Review)
}

\author{
Anrilia E. M. Ningdyah, Edward Helmes, and Claire Thompson \\ College of Healthcare Sciences, Department of Psychology \\ Townsville Campus, James Cook University
}

\author{
Garry Kidd \\ College of Healthcare Sciences, Department of Psychology \\ Cairns Campus, James Cook University \\ Kenneth Mark Greenwood \\ College of Healthcare Sciences, Department of Psychology \\ Singapore Campus, James Cook University
}

\begin{abstract}
Intense debate on training models used in professional psychology education, including discussion on the specific training models most appropriate for educating future psychologists is far from finished. The authors reviewed articles discussing training models including results of empirical studies in professional psychology programs, which were published in several psychology journals databases (1949 to 2014). The authors have identified (a) the scientist-practitioner; (b) the practitioner model and its derivatives; (c) the clinical-scientist; and (d) the competency-based models. This article also outlines the historical development of each model and a consideration of the main principles espoused by each training model. It seems that discussion on the concept of training models and empirical studies on how these models are used in professional psychology programs outside the context of Western countries, is rare. Thus, this review could serve as a theoretical foundation for the implementation of a study aimed at filling the gap in the discussion of professional psychology program curricula, including the training models used, especially in other contexts than the Western.
\end{abstract}

Keywords: professional psychology, training model, psychology curriculum, psychologist

Diskusi intensif tentang model pelatihan spesifik yang paling cocok untuk mendidik psikolog di masa depan masih belum tuntas. Para penulis menelaah artikel-artikel yang mendiskusikan model pelatihan, termasuk yang meliputi hasil studi empiris dalam pendidikan psikologi professional, serta telah diterbitkan dalam berbagai pangkalan data psikologi (1949 hingga 2014). Para penulis mengidentifikasi model-model (a) ilmuwan-praktisi; (b) praktisi dan turunannya; (c) ilmuwan klinis; dan (d) model berdasar kompetensi. Artikel ini juga memaparkan secara garis besar perkembangan sejarah dan pertimbangan prinsip-prinsip utama yang menyertai tiap model pelatihan. Ternyata diskusi tentang konsep model pelatihan dan studi empiris tentang bagaimana model-model tersebut dipakai dalam program psikologi profesional di luar konteks negara Barat, masih langka. Telaah pustaka ini dapat menjadi dasar teoretis pengimplementasian suatu studi yang bertujuan mengisi kesenjangan diskusi kurikulum program psikologi profesional, termasuk model-model pelatihan yang dipakai, terutama di luar konteks negara Barat.

Kata kunci: psikologi professional, model pelatihan, kurikulum psikologi, psikolog

The determination of appropriate preparation for educating future professionals is an important topic given the strategic role of professionals in serving the

The first author wishes to acknowledge the Indonesia Endowment Fund for Education (the Indonesian acronym is, LPDP) for providing a scholarship to pursue a $\mathrm{PhD}$ degree.

Correspondence concerning this article should be addressed to Anrilia E. M. Ningdyah, College of Healthcare Sciences, Department of Psychology. 1 James Cook Drive, Townsville, QLD, Australia 4811. E-mail: anrilia.ansyorideas@my.jcu.edu.au and anrilia_ema@yahoo.com community (Shulman, 2005). Professional education in psychology began in 1896 with the establishment of the first psychological clinic by Lightner Witmer at the University of Pennsylvania (Cautin \& Baker, 2014; Routh, 2000). Following this, several professional programs were established throughout the United States (Routh, 2000). Professional education in psychology is distinguished by some special characteristics not found in traditional scientific/research pro- 
grams. These include: integration between scientific research and practice components (Helmes, 2011); a greater emphasis on professional ethics and codes of conduct (R. L. Peterson, D. R. Peterson, Abrams, \& Stricker, 1997); and, the use of comprehensive teaching and learning methods which involve more than one method to provide knowledge and skills training and nurture professional attitudes (Kaslow, 2004; Peterson et al., 1997). For a more complete review of the characteristics of professional psychology education, please refer to Ningdyah (2014).

Professional psychology training models were discussed intensively for the first time in 1949. Some scholars and psychology professionals of the time contended that education of psychologists should be standardized in order to meet society's demands (Baker \& Benjamin Jr., 2000; Cautin \& Baker, 2014). Previously, there was no consensus or rules regarding the structure of professional psychology education. The Boulder Conference of 1949 marked the first and the most well-known effort to standardize the education of psychologists (Baker \& Benjamin Jr., 2000; Cautin \& Baker, 2014). One of its main outcomes was the emergence of the scientist-practitioner model, the first specifically directed at training professional psychologists, and, until recently, the default framework for the majority of professional programs (Baker \& Benjamin Jr., 2000; Bell \& Hausman, 2014; Belar \& Perry, 1992; Horn, Troyer, \& Hall, 2007). Other educational models were developed as alternatives to the scientist-practitioner model, namely the practitioner model and its variations, the clinical-scientist and competency-based models.

An understanding of the training models is important because it reflects the academic philosophy used in organizing an educational program (Horn et al., 2007), which in turn will also influence the characteristics of graduates. In this paper, the authors review the literature of the training models applied in professional psychology education and outline the current knowledge pertaining to this topic. It is hoped that this review might contribute to understanding of the training model alternatives available in professional psychologist education. This is of particular significance for professional psychology educators, providers of professional psychology programs and policy makers in the area of professional psychology education. For these targets, a full understanding of the training models is expected to assist in: (1) determining the most suitable training model(s) in accordance with the desired goal(s) of the program establishment; and (2) determining educational activities appropriate to the chosen training model(s).

\section{Method}

The author reviews literature published between 1949 and 2014 (when this study was begun) regarding training models applied in professional psychology education. As described above, such training models have been intensively discussed since 1949 when scholars and professionals began to realize the importance of standardizing the education of future psychologists. Thus, the year 1949 was used as the starting point for this review.

The literature has been explored systematically through databases such as Sage, JSTOR, PsycINFO (ProQuest), PsycARTICLES (ProQuest), Scopus, Gale, and Science Direct. The author used the following keywords for the search: 'professional psychology AND training model'; 'professional psychologists AND training model; and 'psychologist AND training model'. In the following section, an overview is presented of each of the professional psychology education training models, including the history of development and basic principles of each.

\section{Results}

\section{Training Models in Professional Psychology Education}

\section{Scientist-Practitioner Model}

This model was developed at the 1949 Boulder Conference on Graduate Education in Clinical Psychology, held in Boulder, Colorado (Raimy, 1950, as cited in Baker \& Benjamin, Jr., 2000; Cautin \& Baker, 2014). It constitutes the first formal statement on the structure of education for future psychologists. The main principle adopted by the scientistpractitioner model is the integration of science and practice in psychology training programs. Thus, according to this model, such programs should comprise scientific method (including training in conducting research) and practice components that aim to develop practice skills. Practice components are taught through the use of the internship or apprenticeship learning method, whereas the scientific component is taught through guiding students in conducting research and writing research reports (Cautin \& Baker, 2014). Psychologists, according to the scien- 
tist-practitioner model, "could and should be both researchers and practitioners" (Belar \& Perry, 2005, as cited in Rodolfa, Kaslow, Stewart, Keilin, \& Baker, 2005b, p. 26).

The Gainesville Conference in Florida in 1990 further formulated important characteristics of the scientist-practitioner model (Belar \& Perry, 1992). The conference resulted in a detailed formulation of learning materials applied in preparing a scientistpractitioner, as summarized in Table 1.

As stated previously, the scientist-practitioner model is the model most widely used in professional psychology programs (Baker \& Benjamin Jr., 2000; Bell \& Hausman, 2014; Belar \& Perry, 1992; Horn, Troyer, \& Hall, 2007). Although it was originally formulated to direct education in clinical psychology, it was also subsequently widely accepted by other fields of psychology (i.e., educational, counselling, industrial and organizational psychology) (Baker \& Benjamin Jr., 2000; Belar \& Perry, 1992; Bell \& Hausman, 2014; Horn et al., 2007).

\section{Practitioner Models}

Decades after its emergence, a group of psychologists came to believe that the scientist-practitioner model fell short of expectations in developing competent clinical psychologists with a full professional skill set (Cautin \& Baker, 2014; Korman, 1974). This group viewed the scientist-practitioner model as producing graduates whose responsiveness to social problems tended to be inadequate. They attempted to address this perceived shortfall by formulating the practitioner model (Korman). This alternative model was presented in the Vail Conference in Vail, Colorado in 1973. Around the same time, a new professsional psychology educational structure emerged, the Doctor of Psychology or PsyD (Korman). Independent professional programs incorporating the new structure were first established in California in 1970, and a few years later similar programs were being implemented throughout the United States (Cautin \& Baker).

Some of the main principles of the practitioner model are as follows:

(1) Consideration of client need in providing psychological services. Accordingly, the curriculum of psychology education programs should be based on the analysis of those needs (Korman, 1974). Consistent with this view, it is important that effort should be made to periodically monitor the extent to which professional programs meets the needs of the community. When required, curriculum changes need to be implemented in meeting these needs.

(2) Students should be selected on the basis of appropriate personality and motivational factors, in addition to test scores. Thus, applicants' experiences in social areas, interpersonal skills and attitudinal factors were deemed important in selecting students likely to develop into psychologists responsive to the needs of clients (Korman, 1974).

(3) Providing students with varied practical experiences related to the needs of society, and emphasis on the importance of program evaluation to identify improvements and opportunities that need to be made available to students.

Several variations of the practitioner model developed: the practitioner-scholar, scholar-practitioner, and local-clinical-scientist models. All three share some basic principles, especially emphasis on the practice component. The practitioner-scholar and scholar-practitioner models are often seen as interchangeable (Bell \& Hausman, 2014). These two models place greater emphasis on scientific activities than the traditional practitioner model. The third variation of the practitioner model is the local-clinical scientist. This model was initiated by the National Council of Schools and Programs of Professional Psychology/NCSPP (R. L. Peterson, D. R. Peterson, Abrams, Stricker, \& Ducheny, 2010). It emphasizes the importance of the 'local' aspects of clients in the provision of psychological services (Bell \& Hausman, 2014; Peterson et al., 2010). Local aspects may include personal and family history, the influence of local social and environmental factors, and the client's personal concerns (Peterson et al.). A principle integral to this model is that psychologists should be sensitive to the specific needs of their clients. Thus, students are afforded broad practice opportunities to expose them to experience a variety of practice experiences, including social and power issues, and serving marginal groups. Students are also exposed to a variety of research topics and research methods (Peterson et al.).

\section{Clinical-Scientist Model}

Further criticism of the scientist-practitioner model emerged in the 1990s, with the establishment of the Academy of Psychological Clinical Science (APCS). The APCS is dominated by clinical psychologists with strong research backgrounds. These founders of the clinical-scientist model argued that the scientist-practitioner model was less appropriate 
Table 1

Learning Content Within the Framework of the Scientist-Practitioner Model (Belar \& Perry, 1992, p. 72-74)

\begin{tabular}{|c|c|c|}
\hline \multirow{2}{*}{$\begin{array}{l}\text { Mode of } \\
\text { Delivery }\end{array}$} & \multicolumn{2}{|r|}{ Components } \\
\hline & Scientific & Practice \\
\hline Teaching & $\begin{array}{l}\text { Scientific core: normal \& } \\
\text { abnormal behavior, human } \\
\text { life span development, } \\
\text { individual differences, } \\
\text { scientific \& professional } \\
\text { ethics, research designs \& } \\
\text { methodology, statistics, } \\
\text { psychological measurement, } \\
\text { history \& systems of } \\
\text { psychology, biological- } \\
\text { cognitive/affective and social } \\
\text { bases of behavior. } \\
\text { - Additional scientific content: } \\
\text { assessment, intervention. }\end{array}$ & $\begin{array}{l}\text { Developing working relationships, communication skills, } \\
\text { interviewing procedures and consultation skills; } \\
\text { case/problem conceptualization based on valid psychological } \\
\text { assessment and scientific sources; scientifically validated } \\
\text { interventions; personal characteristics and their impacts on } \\
\text { professional interactions; analysis of risks and benefits of } \\
\text { assessment and intervention, informed consent, and } \\
\text { iatrogenic issues; ethical, legal and professional obligations } \\
\text { related to the use of scientifically-based assessment and } \\
\text { interventions; socialization into the professional practice of } \\
\text { psychology; the implications of individual differences in } \\
\text { practice, includingcultural and ethnic factors; supervision }\end{array}$ \\
\hline Experiential & $\begin{array}{l}\text { The availability of scientific } \\
\text { experiences, including } \\
\text { conducting formal research } \\
\text { experiences. } \\
\text { - The inclusion of a pre- } \\
\text { dissertation research project } \\
\text { and the dissertation. }\end{array}$ & $\begin{array}{l}\text { Systematic application of psychological knowledge to } \\
\text { practice with individuals, groups, and organization. } \\
\text { - The use of scientific methods (i.e., critical thinking, } \\
\text { hypothesis testing) both in psychological practice and } \\
\text { research. } \\
\text { - Broad and general component of practice, which includes } \\
\text { experiences across a broad variety of settings and } \\
\text { populations. The focus of experiential content of practice } \\
\text { includes case/problem formulation, assessment, intervention, } \\
\text { evaluation, and consultation. } \\
\text { - The provision of early experiential activities under the } \\
\text { guidance of academics, followed by external placements. } \\
\text { - The inclusion of issues of ethics and social and legal } \\
\text { responsibility. } \\
\text { - Consideration of issues related to individual differences } \\
\text { including cross-cultural and multiethnic factors. } \\
\text { - The inclusion of a one year, post-practica, intensive } \\
\text { supervised predoctoral practice experience. } \\
\text { - The practice component begins during the first year and } \\
\text { focuses on the systematic application to practice of } \\
\text { knowledge from core scientific substantive areas. } \\
\text { - Internship as a model for supervised field experiences is } \\
\text { acknowledged. }\end{array}$ \\
\hline
\end{tabular}

in training future psychologists, due to its lack of emphasis on research and on application of psychological sciences in an education context.

The clinical-scientist model places great emphasis on scientific aspects and the research component. While the scientist-practitioner model acknowledges the role of research in psychological practice, the clinical-scientist model places more priority on scientific aspects in the education arena (McFall, 2006).There are no specified requirements that must be met in order for a program to qualify as a clinical-scientist program, but it is expected that the model be individualized, integrated and flexible, and that each professional program be encouraged to maximize its resources to achieve program objectives in line with principles of the clinical-scientist model (Bell \& Hausman, 2014). The following points outline some of the main objectives of the clinical-scientist program (McFall, 2006, p. 36): (1) to train students for a career in the field of clinical research; graduates are expected to generate and apply scientific knowledge; (2) to develop research and 
clinical theory as well as integration with other sciences; (3) to support the development and expansion of access to multiple varied opportunities for training and conducting research, including obtaining research financial support and if desired embarking on a career in the field of clinical sciences; (4) to encourage dissemination of clinical science and its application to human problems in an innovative and responsible way; and (5) to encourage the spread of clinical knowledge to policy makers, fellow psychologists and other scientists and practitioners.

\section{Competency-Based Model}

The aforementioned models are classified as content-based models. Variations of training models in this category are determined by the characteristics of educational program content, be it an emphasis on practice content as seen in the practitioner models, the highlighting of scientific aspects and the conducting of research as applied in the clinicalscientist model, or the balanced view on the role of science and practice advocated by the scientistpractitioner model. The fourth model - the competency-based model - focuses more on a set of competencies that must be achieved upon the completion of a graduate professional psychology program, rather than merely arguing for the inclusion of particular content or subject matter. Thus, this model emphasizes student acquisition of a set of knowledge, skills and attitudes. The competency model also stresses the application of several teaching/learning methods to ensure that graduates achieve the stated competencies and required competency levels.

Key components that characterize the competency model are: (1) a precise description of competencies to be achieved; (2) a tool or method for measuring competencies; and (3) the application of established standards by which a person is considered competent (US Department of Education, National Center for Education Statistics, 2002, p. 9).

The use of the competency-based model in professional psychology education commenced in the United States in 1986 when the National Council of Schools and Programs of Professional Psychology (NCSPP, 2014) issued statements indicating that the competency model would consist of six core competencies (Rodolfa et al., 2014). A number of initiatives to develop models of professional competence in psychology emerged over the next few years, formulated by academics. These include the Competency Cube proposed by Rodolfa et al. (2005a) and the Competency Benchmarks developed by Fouad et al. (2009). Further, such initiatives were also espoused by professional organizations and accreditation bodies of professional psychology programs (for example, the Association of State and Provincial Psychology Boards, 2009; the Mutual Recognition Agreement (Canadian Psychological Association, 2011) from the Canadian Provincial and Territorial Regulatory Bodies; APA Office of Program Consultation and Accreditation (2013), and the British Psychological Society (BPS), 2014).

Discussions in the area of professional competencies in psychology are ongoing. A recent development has been the emergence of a more specific set of competencies, such as the Developmental Achievement Level (NCSPP, 2014) and the Competency Benchmarks (Fouad et al., 2009). With targeted competencies to be achieved in the professional program formulated in detail, competency objectives for each year of education can be mapped so as to enable programs to focus on the achievement of competencies at each level within the period of training. Furthermore, there also appears to be significant movement towards developing assessment methods to measure competencies in a comprehendsive manner, as described, for example, in the Competency Assessment Toolkit (Kaslow et al., 2009).

In summarising several training models used in professional psychology education, Table 2 (see Appendix) presents the main characteristics of the four training models identified above.

\section{Discussion}

In this paper, four main professional psychology program training models have been identified and described: the scientist-practitioner, practitioner, clinical-scientist and competency-based models. It is hoped that this article might provide useful information for psychology educators and those involved in the management of professional psychology programs in determining the most appropriate training model(s) that best suit each program's mission and objectives.

The four training models identified above - (a) the scientist-practitioner; (b) the practitioner model and its derivatives which include the practitionerscholar and the local-clinical-scientists models; (c) the clinical scientists; and (d) the competency-based models - are major training models intensively discussed in the literature reviewed. While the author 
acknowledges the existence of other, less dominant training models used in the education of professional psychologists, as appeared, for example, in the study conducted by Rodolfa et al. (2005b) in the US internship training programs, this paper limits comprehensive discussion of aims and objectives, teaching and learning methods, and evaluation mechanisms to the four training models most commonly referenced in the literature reviewed. The author acknowledges the limitations of this review, and suggests that other reviews might be undertaken to specifically address other developing training models in professional psychology education.

Another important result of the author's literature review is the realisation that the concept of training models and empirical studies on their use in professional psychology programs derive from a Western countries such as the US (e.g., Horn et al., 2007; Rodolfa et al., 2005b) and Australia (e.g., Pachana, O'Donovan, \& Helmes, 2006). Reports on the use of training models in professional psychology education outside these contexts - in Asia, for example are rare. Thus, several important questions remain unanswered: What training models are used by professional psychology programs in non-Western countries? Do trends and models used in Western countries surface in the characteristics of professional psychology education in other regions, such as Asia?

Narrowing focus to the Indonesian context, the author observes that there is very little information on the nature of professional psychology programs. In fact, no empirical studies on the characteristics of professional psychology education in Indonesia have been undertaken to this point. Thus, further research on Indonesian professional psychology education training models and program curriculum structure is required in order to bridge this gap in the literature. Given the increasing number of international postgraduate professional psychology programs (Helmes \& Pachana, 2005), including in Asia (Shimoyama, as cited in Helmes \& Pachana, 2005) and specifically Indonesia (Sarwono, 2004), the author believes that a comprehensive study on the educational characteristics of such professional psychology programs is crucial.

\section{Limitations}

The authors acknowledge the existence of other, less dominant training models used in the education of professional psychologists, as appeared, for example, in the study conducted by Rodolfa et al. (2005b) in the US internship training programs. This paper limits comprehensive discussion of aims and objectives, teaching and learning methods, and evaluation mechanisms to the four training models most commonly referenced in the literature reviewed. The author acknowledges the limitations of this review, and suggests that other reviews might be undertaken to specifically address other developing training models in professional psychology education.

\section{Conclusion}

Knowledge and understanding of various professional psychology education training models is important in providing a foundation towards defining a training model to be used that matches the program objectives. Determination of the training model(s) to be used in a professional program is essential, serving as a guide in developing a series of appropriate educational experiences for students, as well as in planning teaching/learning techniques and in developing an effective evaluation system. One of the expected final outcomes of such programs is ensuring a consistent and integrated educational approach in preparing future psychologists.

\section{References}

American Psychological Association Office of Program Consultation \& Accreditation. (2013). Guidelines and pinciples for accreditation of programs in professional psychology. Retrieved from http://www.apa.org/ed/accreditation/about/policie s/guiding-principles.pdf

Association of State and Provincial Psychology Boards. (2009). History. Retrieved from http:// www.asppb.net/?page $=$ History

Baker, D. B., \& Benjamin Jr., L. T. (2000). The affirmation of the scientist-practitioner: A look back at Boulder. American Psychologist, 55(2), 241-247.

Belar, C. D., \& Perry, N. W. (1992). National conference on scientist-practitioner education and training for the professional practice of psychology. American Psychologist, 47(1), 71-75. doi:10.103 7/0003-066X.47.1.71

Bell, D. J., \& Hausman, E. M. (2014). Training models in professional psychology doctoral programs. In N. J. Kaslow \& W. B. Johnson (Eds.), The Oxford handbook of education and training in professional psychology. New York: Oxford University Press. 
British Psychological Society. (2014). Standards for the accreditation of doctoral programmes in clinical psychology. Leicester: British Psychological Society.

Canadian Psychological Association. (2011). Accreditation standards and procedures for doctoral programmes and internships in professional psychology. Retrieved from http://www.cpa.ca/docs/ File/Accreditation/Accreditation_2011.pdf

Cautin, R. L., \& Baker, D. B. (2014). Training models in professional psychology doctoral programs. In Nadine J. Kaslow \& W. B. Johnson (Eds.), The Oxford handbook of education and training in professional psychology. New York: Oxford University Press.

Fouad, N. A., Grus, C. L., Hatcher, R. L., Kaslow, N. J., Hutchings, P. S., Madson, M. B., Collins, F. L., \& Crossman, R. E. (2009). Competency benchmarks: A model for understanding and measuring competence in professional psychology across training levels. Training and Education in Professional Psychology, 4(Suppl.), S5-S26.

Helmes, E. (2011). North meets South: Perspectives on training in clinical psychology in Canada and Australia, with comments on Singapore. In H. Shimoyama (Ed.), An international comparison of clinical psychology in practice: West meets East (pp. 119-143). Tokyo, Japan: KazamaShobo Inc.

Helmes, E., \& Pachana, N. A. (2005). Professional doctoral training in psychology: International comparison and commentary [Electronic Version]. Australian Psychologist, 40, 45-53.

Horn, R. A., Troyer, J. A., \& Hall, E. J. (2007). The scientist-practitioner model: A rose by any other name is still a rose. The American Behavioral Scientist [H.W.Wilson - SSA], 50(6), 808.

Kaslow, N. J. (2004). Competencies in professional psychology. The American Psychologist, 59(8), 774-781. doi:10.1037/0003-066X.59.8.774

Kaslow, N. J., Grus, C. L., Campbell, L. F., Fouad, N. A., Hatcher, R. L., \& Rodolfa, E. R. (2009). Competency assessment toolkit for professional psychology. Training and Education in Professional Psychology, 3(4S), S27-S45. doi:10.1037/ a0015833

Korman, M. (1974). National conference on levels and patterns of professional training in psychology: The major themes. American Psychologist, 29(6), 441-449. doi:10.1037/h0036469

McFall, R. M. (2006). Doctoral training in clinical psychology. Annual Review of Clinical Psychology, 2(1), 21-49. doi:10.1146/annurev.clinpsy.2.
022305.095245

Mutual Recognition Agreement. (2011). Mutual recognition agreement of the regulatory bodies for professional psychologists in Canada. Retrieved from http://www.cpa.ca/ docs/File/MRA.pdf

National Council of Schools and Programs of Professional Psychology (NCSPP). (2014). Competency developmental achievement levels. Retrieved from http://www.thencspp.com/DALof\%20NCS PP\%209-21-07.pdf

Ningdyah, A. E. M. (2014). Graduate professional education in psychology: Its essential characteristics. Paper presented at the Social Science, Economics International Conference. Palembang: Bina Darma University.

Pachana, N. A., O'Donovan, A., \& Helmes, E. (2006). Australian clinical psychology training program directors survey. Australian Psychologist, 41, 168-178.

Peterson, R. L., Peterson, D. R., Abrams, J. C., \& Stricker, G. (1997). The national council of schools and programs of professional psychology education model. Professional Psychology: Research and Practice, 28(4), 373-386. doi:10.1037/07357028.28.4.373

Peterson, R. L., Peterson, D. R., Abrams, J. C., Stricker, G., Ducheny, K. (2010). In M. B. Kenkel \& R. L. Peterson (Eds.), Competency-based education for professional psychology (pp. 1342). Washington, DC, US: American Psychological Association, x, 286 pp. http://dx.doi.org/10.10 37/12068-001

Rodolfa, E. R., Bent, R. J., Eisman, E., Nelson, P. D., Rehm, L., \& Ritchie, P. (2005a). A cube model for competency development: Implications for psychology educators and regulators. Professional Psychology: Research and Practice, 36, 347-354.

Rodolfa, E. R., Kaslow, N. J., Stewart, A. E., Keilin, W. G., \& Baker, J. (2005b). Internship training: Do models really matter? Professional Psychology: Research and Practice, 36(1), 25. doi:10.10 37/0735-7028.36.1.25

Rodolfa, E., Baker, J., DeMers, S., Hilson, A., Meck, D., Schaffer, J., Webb, C. (2014). Professional psychology competency initiatives: Implications for training, regulation, and practice. South African Journal of Psychology, 44(2), 121-135. doi:10.1177/ 0081246314522371

Routh, D. K. (2000). Clinical psychology training: A history of ideas and practices prior to 1946. American Psychologist, 55(2), 236.

Sarwono, S. W. (2004). Psychology in Indonesia. In M. J. Stevens \& D. Wedding (Eds.), Handbook of 
international psychology. New York: BrunnerRoutledge.

Shulman, L. S. (2005). Signature pedagogies in the professions. Daedalus, 134(3), 52-59. doi:10.116 2/0011526054622015

U.S. Department of Education, National Center for Education Statistics. (2002). Defining and Assess- ing Learning: Exploring Competency-Based Initiatives, NCES 2002-159, prepared by Elizabeth A. Jones and Richard A. Voorhees, with Karen Paulson, for the Council of the National Postsecondary Education Cooperative Working Group on Competency-Based Initiatives. Washington, DC U.S. Department of Education ED Pubs.

\section{Appendix}

Table 2

The Main Characteristics of the Four Major Training Models in Professional Psychology Education

\begin{tabular}{|c|c|c|c|c|}
\hline \multirow{2}{*}{$\begin{array}{l}\text { Curriculum } \\
\text { Components }\end{array}$} & \multicolumn{4}{|c|}{ Training Models } \\
\hline & $\begin{array}{l}\text { Scientist- } \\
\text { Practitioner }\end{array}$ & Practitioner & Clinical Scientists & $\begin{array}{l}\text { Competency- } \\
\text { based }\end{array}$ \\
\hline $\begin{array}{l}\text { Philosophy/Main } \\
\text { Principles }\end{array}$ & $\begin{array}{l}\text { The integration } \\
\text { of science and } \\
\text { practice: } \\
\text { integrated model } \\
\text { in professional } \\
\text { psychology } \\
\text { education. } \\
\text { - Equal emphasis } \\
\text { on both science } \\
\text { and practice. }\end{array}$ & $\begin{array}{l}\text { - Clinical practice and } \\
\text { service delivery } \\
\text { emphasis. } \\
\text { - Increased } \\
\text { consideration of } \\
\text { client needs both in } \\
\text { service delivery and } \\
\text { choice of } \\
\text { curriculum. } \\
\text { - Varied practical } \\
\text { experiences to fulfil } \\
\text { the needs of society. } \\
\text { - Professional training } \\
\text { setting that is well- } \\
\text { suited to the needs } \\
\text { of a range of clients } \\
\text { in the community. } \\
\text { - Broad and } \\
\text { indiscriminate } \\
\text { psychological } \\
\text { services. } \\
\text { - Consideration of } \\
\text { 'local aspects' of } \\
\text { clients (this only } \\
\text { applies for the local- } \\
\text { clinical-scientist } \\
\text { model). }\end{array}$ & $\begin{array}{l}\text { - Strong emphasis on } \\
\text { scientific aspects and } \\
\text { research components. } \\
\text { - Increased attention to } \\
\text { the role of } \\
\text { psychological science } \\
\text { in professional } \\
\text { education. } \\
\text { - Scientific evidence } \\
\text { and empirically } \\
\text { supported treatment } \\
\text { emphasis. }\end{array}$ & $\begin{array}{l}\text { More emphasis } \\
\text { on a set of } \\
\text { competencies } \\
\text { that must be } \\
\text { achieved upon } \\
\text { completion of } \\
\text { graduate } \\
\text { professional } \\
\text { psychology } \\
\text { program. } \\
\text { - Attention } \\
\text { directed towards } \\
\text { student } \\
\text { acquisition of a } \\
\text { set of } \\
\text { knowledge, } \\
\text { skills and } \\
\text { attitudes. }\end{array}$ \\
\hline
\end{tabular}




\begin{tabular}{|c|c|c|c|c|}
\hline \multirow{2}{*}{$\begin{array}{l}\text { Curriculum } \\
\text { Components }\end{array}$} & \multicolumn{4}{|c|}{ Training Models } \\
\hline & $\begin{array}{c}\text { Scientist- } \\
\text { Practitioner }\end{array}$ & Practitioner & Clinical Scientists & $\begin{array}{c}\text { Competency- } \\
\text { based }\end{array}$ \\
\hline $\begin{array}{l}\text { Aims and } \\
\text { Objectives }\end{array}$ & $\begin{array}{l}\text { To train } \\
\text { professional } \\
\text { psychologist to } \\
\text { become both } \\
\text { researcher and } \\
\text { practitioner. }\end{array}$ & $\begin{array}{l}\text { To prepare } \\
\text { professional } \\
\text { psychologist to } \\
\text { competently conduct } \\
\text { clinical work. } \\
\text { - } \text { To train students to } \\
\text { become } \\
\text { psychologists } \\
\text { sensitive to the } \\
\text { social problems and } \\
\text { needs of the client } \\
\text { community. }\end{array}$ & $\begin{array}{l}\text { - To train research } \\
\text { scientists for meeting } \\
\text { diverse roles in the } \\
\text { psychological field. } \\
\text { - } \text { To prepare students } \\
\text { for a career in the } \\
\text { field of clinical } \\
\text { research. } \\
\text { To prepare students } \\
\text { with a sound } \\
\text { grounding in } \\
\text { scientific knowledge } \\
\text { and methods. } \\
\text { - To develop research } \\
\text { and clinical theory as } \\
\text { well as integration } \\
\text { with other sciences. } \\
\text { To support the } \\
\text { development and } \\
\text { expansion of access to } \\
\text { varied opportunities } \\
\text { for training and } \\
\text { conducting research. } \\
\text { To encourage } \\
\text { dissemination of } \\
\text { clinical science and its } \\
\text { application to human } \\
\text { problems. } \\
\text { To encourage the } \\
\text { spread of clinical } \\
\text { knowledge to policy } \\
\text { makers, colleagues } \\
\text { within the psychology } \\
\text { field and other } \\
\text { scientists and } \\
\text { practitioners }\end{array}$ & $\begin{array}{l}\text { To ensure that } \\
\text { students develop } \\
\text { and achieve } \\
\text { particular skills, } \\
\text { knowledge and } \\
\text { abilities deemed } \\
\text { essential in the } \\
\text { practice of } \\
\text { psychology. }\end{array}$ \\
\hline $\begin{array}{l}\text { Content/Subject } \\
\text { Matter Emphasis }\end{array}$ & 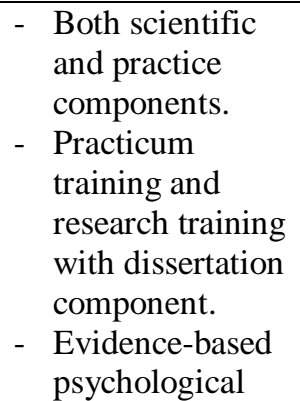 & $\begin{array}{l}\text { - More emphasis on } \\
\text { the practitioner } \\
\text { components without } \\
\text { neglecting } \\
\text { comprehensive } \\
\text { psychological } \\
\text { science and } \\
\text { empirical } \\
\text { investigation. }\end{array}$ & $\begin{array}{l}\text { - More emphasis on the } \\
\text { scientific and research } \\
\text { components. } \\
\text { - A broad range of } \\
\text { specific knowledge } \\
\text { and skills, tailored to } \\
\text { the needs of the } \\
\text { student and the } \\
\text { particular problems } \\
\text { being explored. }\end{array}$ & $\begin{array}{l}\text { - The focus of this } \\
\text { model is not the } \\
\text { completion of a } \\
\text { set of } \\
\text { subjects/specified } \\
\text { content and/or a } \\
\text { number of hours } \\
\text { of supervised } \\
\text { practice. }\end{array}$ \\
\hline
\end{tabular}
practice. 


\begin{tabular}{|c|c|c|c|c|}
\hline \multirow{3}{*}{$\begin{array}{l}\text { Curriculum } \\
\text { Components }\end{array}$} & \multicolumn{4}{|c|}{ Training Models } \\
\hline & $\begin{array}{c}\text { Scientist- } \\
\text { Practitioner }\end{array}$ & Practitioner & Clinical Scientists & $\begin{array}{l}\text { Competency- } \\
\text { based }\end{array}$ \\
\hline & & $\begin{array}{l}\text { Required content } \\
\text { includes: evaluation } \\
\text { of service, new } \\
\text { service delivery } \\
\text { systems, practice } \\
\text { and theory } \\
\text { integration, service } \\
\text { program } \\
\text { development and } \\
\text { administration, and } \\
\text { supervision and } \\
\text { training. } \\
\text { - More flexible } \\
\text { dissertation criteria } \\
\text { with an emphasis on } \\
\text { the applied field. }\end{array}$ & & $\begin{array}{l}\text { Instead, the } \\
\text { stated } \\
\text { competencies to } \\
\text { be attained on } \\
\text { graduation of a } \\
\text { program guides } \\
\text { and determines } \\
\text { the educational } \\
\text { experiences } \\
\text { provided for the } \\
\text { students. }\end{array}$ \\
\hline $\begin{array}{l}\text { Teaching and } \\
\text { Learning } \\
\text { Methods }\end{array}$ & $\begin{array}{l}\text { Both didactic } \\
\text { and experiential } \\
\text { methods in } \\
\text { delivering } \\
\text { scientific and } \\
\text { practice } \\
\text { components. }\end{array}$ & $\begin{array}{l}\text { - Learning by doing } \\
\text { and the development } \\
\text { of supervisory } \\
\text { relationships. } \\
\text { - The provision of } \\
\text { field training in } \\
\text { various contexts. } \\
\text { The integration of field } \\
\text { experiences with } \\
\text { skills and } \\
\text { knowledge learned } \\
\text { in the classroom. } \\
\text { - Academics function } \\
\text { as role models by } \\
\text { engaging in } \\
\text { professional works. } \\
\text { - Regular exchange } \\
\text { between academics } \\
\text { and field supervisors } \\
\text { to ensure the } \\
\text { continuation of } \\
\text { professional } \\
\text { development } \\
\text { activities of both } \\
\text { groups. }\end{array}$ & $\begin{array}{l}\text { - Standardization in } \\
\text { training is not } \\
\text { expected; multiple } \\
\text { ways of training are } \\
\text { endorsed to achieve } \\
\text { the goals of the } \\
\text { clinical science } \\
\text { training. } \\
\text { - Several conceptions } \\
\text { regarding training } \\
\text { methods include, for } \\
\text { example, an } \\
\text { apprenticeship model } \\
\text { in which trainees } \\
\text { work closely with a } \\
\text { research mentor on a } \\
\text { topic under } \\
\text { investigation. } \\
\text { - Encouragement of } \\
\text { student sharing } \\
\text { conceptual and } \\
\text { methodological work } \\
\text { activities in academic } \\
\text { forums such as } \\
\text { seminars, tutoring, } \\
\text { posters and colloquia. }\end{array}$ & $\begin{array}{l}\text { A variety of } \\
\text { teaching } \\
\text { /learning } \\
\text { methods are } \\
\text { applied to ensure } \\
\text { that graduates } \\
\text { achieve the } \\
\text { stated } \\
\text { competencies } \\
\text { and required } \\
\text { competency } \\
\text { levels. }\end{array}$ \\
\hline
\end{tabular}




\begin{tabular}{|c|c|c|c|c|}
\hline \multirow{2}{*}{$\begin{array}{l}\text { Curriculum } \\
\text { Components }\end{array}$} & \multicolumn{4}{|c|}{ Training Models } \\
\hline & $\begin{array}{c}\text { Scientist- } \\
\text { Practitioner }\end{array}$ & Practitioner & Clinical Scientists & $\begin{array}{c}\text { Competency- } \\
\text { based }\end{array}$ \\
\hline $\begin{array}{l}\text { Evaluation } \\
\text { Methods and } \\
\text { Emphasis }\end{array}$ & $\begin{array}{l}\text { Two types of } \\
\text { evaluation: } \\
\text { - Student } \\
\text { evaluation to } \\
\text { ensure that } \\
\text { individual's } \\
\text { curriculum is } \\
\text { relevant and } \\
\text { adequate in } \\
\text { achieving the } \\
\text { program's } \\
\text { objective, and to } \\
\text { ensure } \\
\text { integration of the } \\
\text { various training } \\
\text { components. } \\
\text { - Program } \\
\text { evaluationto } \\
\text { monitor } \\
\text { program's } \\
\text { effectiveness in } \\
\text { implementing } \\
\text { the scientist- } \\
\text { practitioner } \\
\text { model. }\end{array}$ & $\begin{array}{l}\text { - Student evaluation: } \\
\text { equal weight on } \\
\text { outstanding } \\
\text { performance in } \\
\text { professional } \\
\text { activities and } \\
\text { empirical/theoretical } \\
\text { achievements. } \\
\text { - Program evaluation: } \\
\text { periodic monitoring } \\
\text { of program } \\
\text { objectives in } \\
\text { meeting society } \\
\text { needs; making } \\
\text { appropriate } \\
\text { curricular changes } \\
\text { where indicated; } \\
\text { regular self- } \\
\text { evaluation and } \\
\text { product evaluation } \\
\text { focusing on } \\
\text { competencies of } \\
\text { graduates and their } \\
\text { impact on society. }\end{array}$ & $\begin{array}{l}\text { - Direct assessment of } \\
\text { students' competence } \\
\text { in targeted areas } \\
\text { through performance } \\
\text { samples that are } \\
\text { highly relevant to } \\
\text { their clinical research } \\
\text { problems. }\end{array}$ & 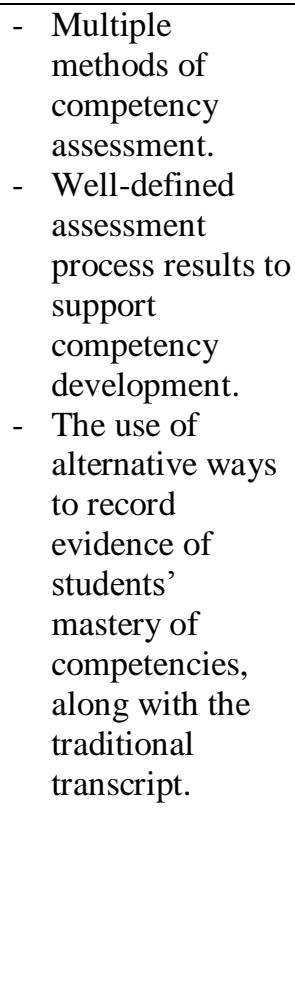 \\
\hline
\end{tabular}

